\title{
THE HOLISTIC CURRICULUM
}

First published in 1988, The Holistic Curriculum addresses the problem of fragmentation in education through a connected curriculum of integrative approaches to teaching and learning. John P. Miller, author of more than seventeen books on holistic education, discusses the theoretical foundations of the holistic curriculum and particularly its philosophical, psychological, and social connections.

Tracing the history of holistic education from its beginnings, this revised and expanded third edition includes new material on Indigenous approaches to education while also expanding upon the six curriculum connections: subject, community, thinking, earth, body-mind, and soul. This edition also includes an introduction by leading Indigenous educator Gregory Cajete, as well as a dialogue between the author and Four Arrows, author of Teaching Truly, about the relationship between holistic education and Indigenous education.

JOHN P. MILLER teaches courses on holistic education and contemplative education at the Ontario Institute for Studies in Education at the University of Toronto, where he is a professor. 
This page intentionally left blank 


\section{JOHN P. MILLER}

\section{The Holistic Curriculum}

Third Edition 
(C) University of Toronto Press 2019

Toronto Buffalo London

utorontopress.com

Printed in the U.S.A.

ISBN 978-1-4875-0413-7 (cloth) ISBN 978-1-4875-2317-6 (paper)

()

Printed on acid-free paper with vegetable-based inks.

Publication cataloguing information is available from

Library and Archives Canada.

University of Toronto Press acknowledges the financial assistance to its publishing program of the Canada Council for the Arts and the Ontario Arts Council, an agency of the Government of Ontario. 